\title{
CHANGES IN WETLANDS IN DHAKA CITY: TRENDS AND PHYSICO-ENVIRONMENTAL CONSEQUENCES
}

\author{
Md. Shahidul Islam ${ }^{1 *}$, Md. Rejaur Rahman ${ }^{2}$, A.K.M. Shahabuddin ${ }^{1}$ and Raquib Ahmed $^{1}$ \\ ${ }^{1}$ Institute of Environmental Science, University of Rajshahi, Rajshahi 6205, Bangladesh; ${ }^{2}$ Department of Geography \\ and Environmental Studies, University of Rajshahi, Rajshai 6205, Bangladesh; \\ *Corresponding author; email: shahidul_rubd@yahoo.com
}

\begin{abstract}
There existed a large number of water bodies including rivers, Khals, lakes and low-lying areas in Dhaka, a thickly populated City and capital of the country. The water bodies played important roles on the natural environment of the City including its drainage system. Due to various natural and human induced reasons, the wetlands of the City have been shrinking with the passage of time. This study makes an attempt to identify the urban wetlands, emphasizing on the extent of their changes and subsequent impacts on physical environment of the area. For ascertaining the land-use pattern of the City, this study uses topographical map (Toposheet of 1960) and satellite images (Landsat TM, 1988 and ALOS VNIR, 2008). It also uses remote sensing and GIS based software (e.g. Arc GIS, Erdas Imagine) for this purpose. Statistical analysis has been carried out in order to process and analyze the data. The study observes that the wetlands of Dhaka city are changing very quickly. In 1960, the total area of water bodies and lowlands were 2952.02 and 13527.58 ha, respectively. Whereas in 1988, the total area of the same decreased to 2103.62 and 12717.73 ha, respectively. This deteriorated further, occupying an area of 1990.71 ha in 2008 which indicates that the lowlands continued to decrease. Thus the water bodies and lowlands decreased by 32.57\% and 52.58\%, respectively during 1960 and 2008 . This changing trend of wetlands makes the drainage system of Dhaka City vulnerable, creating water logging problems and their consequences. Land filling and encroachment were recognized to be the main reasons for changing wetlands in the City.
\end{abstract}

Key words: Wetlands, wetland changes, water logging, environment

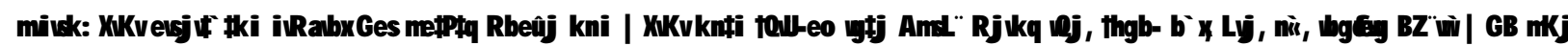

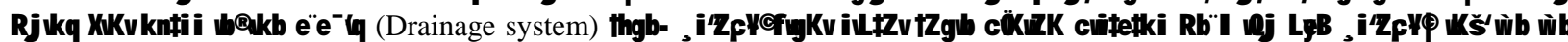

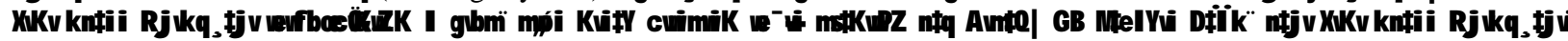

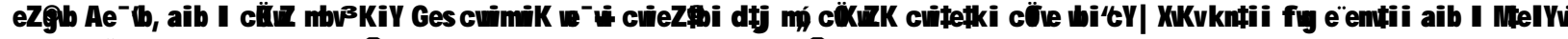

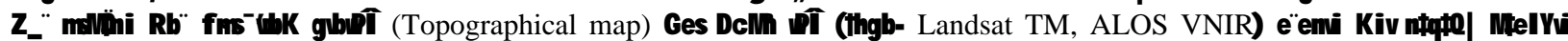

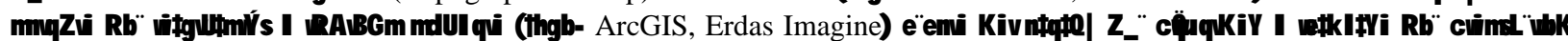

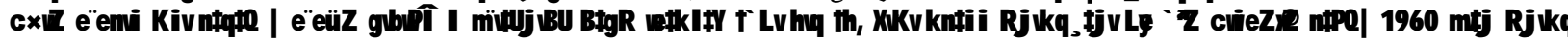

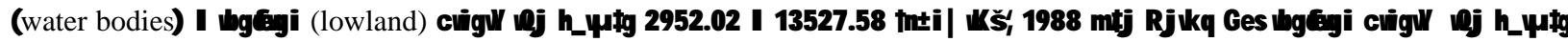

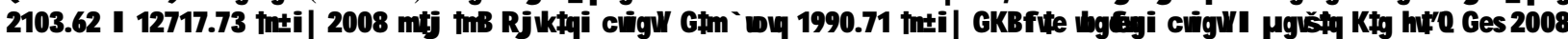

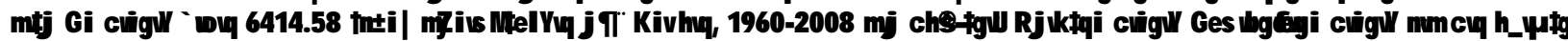

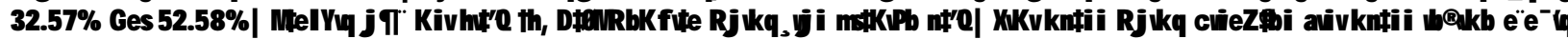

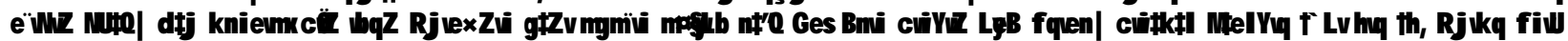

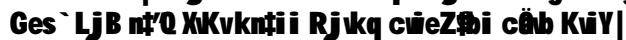

\section{Introduction}

Dhaka City has been suffering from many environmental problems including flooding, water logging and other related problems. In the past the City was regarded as the Venice of the East or the City of Channels (Dani 1962). A few decades ago there were numerous lowlands, khals and channels within and around Dhaka that would drain the City efficiently (JICA 1991). Canals of the City are used to be the connecting channels of the rivers surrounded by the greater Dhaka. But now-a-days, the situation is completely different. The City has spread over the years in all directions and such expansion has caused shrinkage of the natural drainage and wetlands.
Moreover, most of the canals have disappeared and banks of the surrounding rivers are encroached and/or grabbed gradually due to a number of reasons. The major causes are unplanned urbanization, encroachment, lack of co-ordination between government agencies, maintenance to the system and implement of pertinent laws. As a result each year the city dwellers suffer acute water logging problems during the rainy season. In a report on Strategic Environment Assessment of Dhaka, water logging has been identified as one of the major problems of the City (World Bank 2007). During monsoon rains, many areas of Dhaka go under water, because canals, being the primary drainage system of the city are blocked, cannot carry the huge volume of storm water. The situation has 
turned very severe in recent years, and main streets now go under a metre of water after heavy monsoon shower (Islam 2005).

There is no single authority for the management of wetlands in Dhaka City, thus creating a lack of coordination among the concern organizations. Because water logging is one of the major problems of the City, there is an immediate need to implement land use regulations and strict enforcement mechanisms, restrictions to the land encroachment on the bank of the Khals in the city and implementations of cities' urban and drainage master plans (Khan 2001). On the other hand, there is no specific map or well-documented records of wetlands of the City. The land grabbers take this opportunity to encroach the wetlands. It is an urgent need to identify the wetlands, evaluate its trend of changes and their consequences on the wetlands. The aims of this study therefore were to identify the past and present spatial extent of wetlands, their changing patterns during 1960-2008, and the physicoenvironmental consequences on the area.

\section{Geographical location of the study area}

Dhaka city is located in the central part of Bangladesh and situated on the Northern bank of the river Buriganga. The city is bounded by the Balu river in the East, Tongi Khal in the North and Turag river in the West. The study area lies between $90^{\circ} 20^{\prime}$ and $90^{\circ} 30^{\prime}$ east longitude and $23^{0} 40^{\prime}$ and $23^{0} 55^{\prime}$ north latitude (Fig. 1). The study area is included in the survey of Bangladesh Toposheet Nos. $79 \frac{1}{5}$ and $79 \frac{1}{6}$.

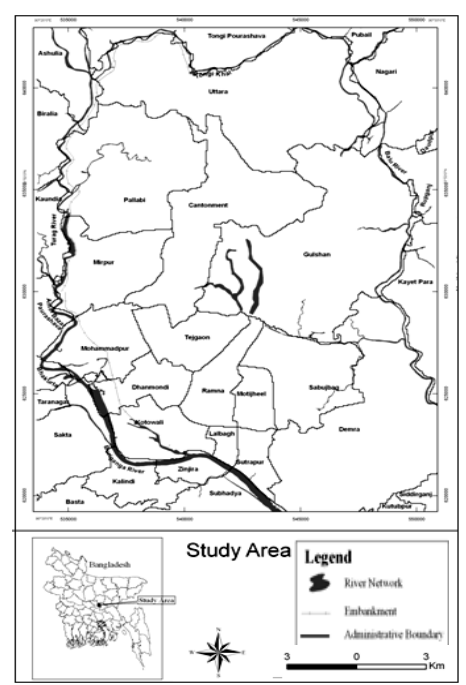

Fig. 1 Study area showing Dhaka City and its surroundings

\section{Major wetlands of the study area}

The surface water area of Dhaka city is about $10-15 \%$ of total land area (DOE, BCAS and UNEP 2006). The surface water of this city is closely dissected by a number of rivers, canals and lakes. The Buriganga, Turag, Tongi Khal and Balu River are the main streams that surround Dhaka city. The major lakes are Dhanmondi lake, Ramna lake, Gulshan lake and Cresent lake. It has been known from different government and non-government organizations and available surface water drainage map that there were more than 35 canals within Dhaka city area (Khan 2001). The conditions of some of the canals are very much critical at present and some of them are already vanished. The major canals which are till used as open channel is Begunbari Khal, Abdullahpur khal, Diabari khal, Manda Khal, Digun Khal, Meradia-Gazaria Khal and Kallayanpur Khal. The low-lying areas of Dhaka city have been broadly identified in the Dhaka Metropolitan Development Plan (DMDP). However the identification of low-lying areas on mouza map is not yet completed. For the purpose of this study the surrounding rivers, the lakes, canals and low-lying areas have considered as wetlands and wetlands are divided into two categories; water bodies and lowlands.

\section{Main processes of wetland changes}

Land filling: Filling in a wetland occurs when earthen or other miscellaneous material is used to fill in the area of a wetland and to raise the final elevation of the site (Nakashima et al 1994). This is done frequently to provide new sites for buildings, infrastructure alignments, and for disposal of garbage and waste. The Private Land Development Companies (PLDCs) implement housing projects in low lying areas with their own style ignoring the existing laws, restrictions and even they are not sincere and co-operative with government agencies. The PLDCs flout laws and fill-up low-lying areas by carrying sand/earth from other areas using country boats and engine boats. In Dhaka city, RAJUK (Rajdhani Unnayan Korporation-Capital Development Corporation) plays key role in implementing public sector housing projects. But the RAJUK is also implementing their housing project in wetland areas like the PLDCs. Therefore, wetlands are shrinking day by day in the Dhaka city.

Encroachment: Wetland encroachment is very common practice in Dhaka city. The first step of encroachment is to build structures along the banks of wetlands and further out on the wetlands itself. To do this, rows and 
bamboo posts are positioned and fixed on the water body bed along the bank and extending into the main body of the wetland. Then huts and shops are built on these stilts. The owners of these structures are then start reclaiming land by earth fills and dumping garbage. Rivers are being encroached upon deliberately filled up and are being held as private property (Khuda 2001). There is another aspect of encroachment, which is done by PLDCs in the study area. A good number of land development companies are involved in land encroachment activities. Each company maintains its tentative boundary adjacent to the project. These companies try to occupy all the lands including wetlands within their tentative boundary.

\section{Methodology}

In this study, both primary and secondary sources of data have been used. To fulfill the objective of this study, the wetland maps of 1960, 1988 and 2008 were derived using topographic map of 1960, Landsat TM satellite image of 1988 and ALOS-VNIR satellite images of 2008. Other relevant maps such as Dhaka City map, Ward map, road map and general land use map were used as ancillary data. The detail information of used maps and images for this study are listed in Table 1.

Table 1. Maps and images used in this study

\begin{tabular}{|c|c|c|}
\hline $\begin{array}{c}\text { Types of data } \\
\text { Toposheet }\end{array}$ & Scale/ resolution & Year \\
\hline $\begin{array}{c}\text { Survey of Bangladesh } \\
\text { Landsat TM image }\end{array}$ & 1960 \\
\hline $\begin{array}{c}\text { Advanced Land } \\
\text { Observation System } \\
\text { (VNIR-Visible, Near } \\
\text { Infrared) }\end{array}$ & $10 \mathrm{~m}$ & 1988 \\
\hline $\begin{array}{c}\text { Dhaka City Corporation } \\
\text { Ward map }\end{array}$ & $1: 26,000$ & 2008 \\
\hline $\begin{array}{c}\text { Dhaka City guide map of } \\
\text { SOB }\end{array}$ & $1: 20,000$ & 1987,1995 \\
\hline $\begin{array}{c}\text { General land use map of } \\
\text { SPARRSO }\end{array}$ & $1: 25000$ & 1991 \\
\hline
\end{tabular}

To derive the wetlands from the topographic map and satellite images, digital image processing technique was performed. The wetlands areas of 1960 were digitized edited and leveled from the Toposheet. Landsat TM image of 1988 and ALOS (VNIR) image of 2008 were used in this study to produce land use/cover categories for the year 1988 and 2008, respectively. Afterwards, wetlands were extracted from the classified maps of
1988 and 2008. To classify the satellite image, supervised digital image processing technique was applied over false colour composite (FCC), which was generated using near-infrared, red and green bands of the satellite images. In supervised classification, first training samples were given for each of the land use/land cover classes. Then maximum likelihood classifier was used for final land use/land cover classification. The Accuracy assessment was done using ERDAS image processing software and overall accuracies of the classified images were found in between $80 \%$ and $84 \%$. In this study, to detect and analyze the wetlands change of Dhaka city, a postclassification comparison technique was used which are the most widely used change detection methods (Jensen 1996).

For this study, the primary data have been collected using observation and field survey questionnaire. For questionnaire survey, five areas were selected purposively form the changed areas of wetland (Fig. 2). Afterwards, the total number of households of these areas was found out with the help of Bangladesh Bureau of Statistics Community Series (BBS Community Series 2007). A total 390 households were selected as samples from selected areas. Yamane's (1970) mathematical formula was used for determining the sample size. On the other hand, secondary data have been collected from various government, semi-government and non-government organizations. After completion of primary data collection from the field, the interviewed questionnaires were processed using Statistical Package for the Social Sciences (SPSS) and Microsoft Excel for Windows. The secondary data used in this research were included after checking their acceptability carefully.

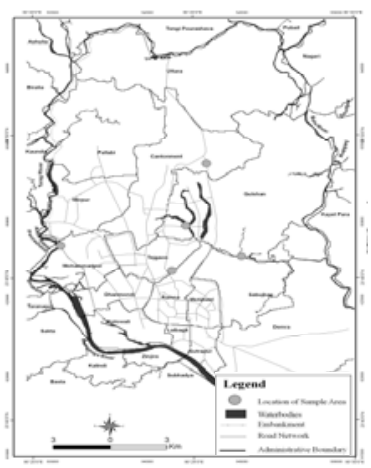

Fig. 2 Sample areas for questionnaire survey

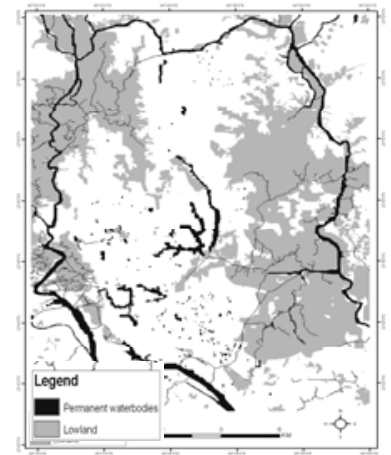

Fig. 3 Wetlands of Dhaka City in 1960

\section{Results and Discussion}

Wetland changes during 1960-2008: It was mentioned earlier that in this study wetlands were divided into two categories; water bodies and lowlands. Using topographical map and satellite images of the stipulated time frame it was observed from the analysis that the 
wetland of Dhaka city was changed dramatically. In 1960 , the total area of water bodies and lowlands was 2952.02 ha (hectares) and 13527.58 ha, respectively (Table 2). In 1988, the area of water bodies was 2103.62 and lowlands 12717.73 ha. But in 2008, the total areas of water bodies and the lowlands were found 1990.71 ha and 6414.57 ha, respectively. So, from this analysis it is clear that the areas under both categories (water bodies and lowlands) of wetlands decreased sharply during the study period. Statistics also shows that $32.57 \%$ of the water bodies and $52.58 \%$ of lowlands decreased from 1960 to 2008 in the study area (Table 2). The spatial extend of the wetlands are shown in Figs. 3-5.

Table 2. Changes in wetlands during 1960-2008

\begin{tabular}{|l|c|c|c|c|c|c|c|c|c|}
\hline $\begin{array}{c}\text { Categorie } \\
\text { s of land } \\
\text { use/cover } \\
\text { types }\end{array}$ & $\begin{array}{c}\text { Area in } \\
1960\end{array}$ & $\begin{array}{c}\text { Area in } \\
1988\end{array}$ & $\begin{array}{c}\text { Area in } \\
2008\end{array}$ & $\begin{array}{c}\text { Changes in } \\
\text { area during } \\
1960- \\
1988\end{array}$ & $\begin{array}{c}\text { Change } \\
(\%)\end{array}$ & $\begin{array}{c}\text { Changes in area } \\
\text { during 1988- } \\
2008\end{array}$ & $\begin{array}{c}\text { Change } \\
(\%)\end{array}$ & $\begin{array}{c}\text { Changes in } \\
\text { area during } \\
1960-2008\end{array}$ & $\begin{array}{c}\text { Change } \\
(\%)\end{array}$ \\
\hline $\begin{array}{l}\text { Water } \\
\text { bodies }\end{array}$ & 2952.02 & 2103.62 & 1990.71 & -848.40 & 28.74 & -112.91 & 5.37 & -961.31 & 32.57 \\
\hline Lowlands & 13527.58 & 12717.73 & 6414.57 & -809.85 & 5.99 & -6303.16 & 49.56 & -7113.01 & 52.58 \\
\hline
\end{tabular}

All figures are in ha.

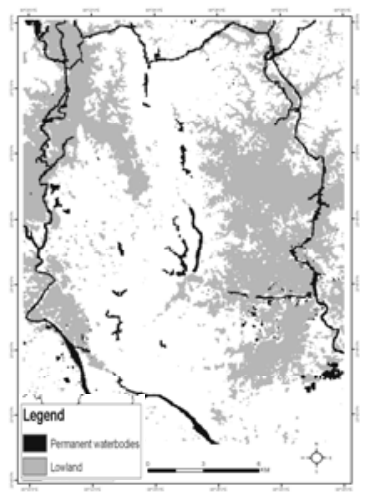

Fig. 4 Wetlands of Dhaka City in 1988

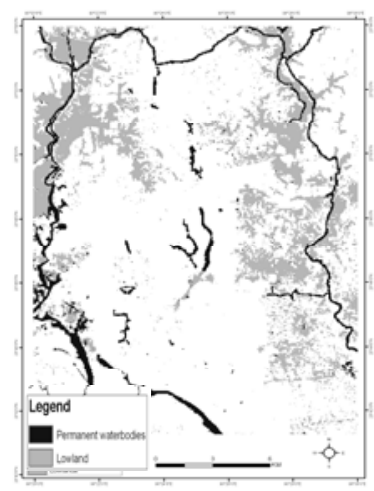

Fig. 5 Wetlands of Dhaka City in 2008
On the other hand, overlay analysis between 1960 and 2008 shows that the shape of lowlands are being changed and from the land use and land cover map of 1960 and 2008 it was observed that this is mainly because of land filling activities in the area. In 1960 lowlands covered most of the eastern part and western edge of the Dhaka city. In 1988, the lowlands of north-eastern part have reduced. Again in 2008, aerial extent of wetlands was reduced drastically both in the eastern part and western edge of the city and became sporadic in nature (Fig. 6). In the south-eastern part of the city, the lowlands areas were decreased mainly at Boro-Magbazar, Eskaton, Modhubag, Noyatola, East-Rampura, Matijheel and Jatrabari (Fig. 6). Lowlands in the north-eastern part mainly decreased at Badda, Satakul, Khilkhet, Askona, Dobadia and Dumni area. It was also observed that in the south-western part, lowlands were mainly decreased at Aminbazar, Gabtoli, Adabor, Ramchandrapur, Katasur and Mohammadpur. In north-western part of the area, lowlands decreased mainly at Diabari, Baunia, Dhaur and Kamarpara areas. From the landuse/land cover map it was observed that the shrinking of lowlands in these areas was mainly due to the land filling in the areas.

In contrast, overlay analysis also shows that the area of water bodies is reduced or shrunk. The width of GulshanBaridara and Dhanmondi lakes has reduced as they shrunk (Fig. 7). Overlay map of water bodies of 1960 and 2008 (Fig. 7) revealed that major change was found in Turag river from Aminbazar to connecting point of Buriganga river. Similarly, during the same period major change occurred in Buriganga river; in the left side of the river at Kamrangirchar area and along the both sides of the river in Bangladesh China Friendship Bridge to Lalbag area.

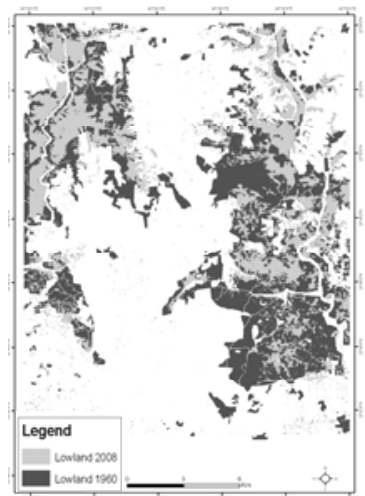

Fig. 6 Changed area: Lowlands (1960-2008)

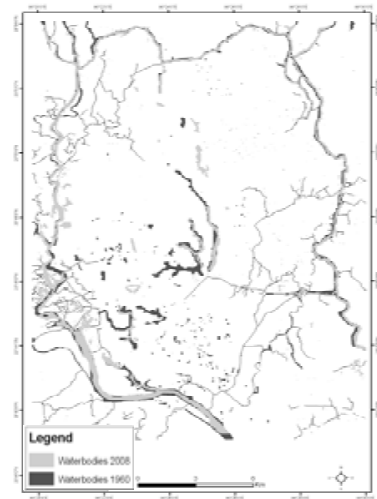

Fig. 7 Changed area: Water bodies (1960-2008)
Consequences of wetland losses: Ecologically wetland has a great importance and loss of wetlands in an area can create a large number of environmental problems. Field survey results of this study revealed that due to the loss of wetlands, $59.4 \%$ of the respondent reported they are facing drainage congestion and water logging 
problems (Table 3), 30.8\% respondent identified the ground water recharge capacity problem and $5.9 \%$ of the respondent identified loss of water reservoirs as the main consequences of loss of wetland.

Drainage congestion and water logging: Dhaka city has experienced significant urban growth during the last 50 years. The land use has undergone radical changes since 1971 when Dhaka became the capital of the new sovereign state of Bangladesh.

Table 3. Impacts of wetland losses on affected people

\begin{tabular}{|l|c|c|}
\hline Impact of wetland loss & Frequency & Percentage \\
\hline Loss of water reservoirs & 23 & 5.9 \\
\hline $\begin{array}{l}\text { Reduced ground water recharge } \\
\text { capacity }\end{array}$ & 119 & 30.8 \\
\hline $\begin{array}{l}\text { Drainage congestion and water } \\
\text { logging }\end{array}$ & 230 & 59.4 \\
\hline Loss of vegetation & 6 & 1.6 \\
\hline Increase Water borne disease & 9 & 2.3 \\
\hline Total & 387 & 100.0 \\
\hline
\end{tabular}

Source: Field survey, 2009

Change in land use pattern alters the physical characteristics of an area, which in turns brings changes in hydrological regime. A study by JICA (1987) observed that many portion of the major drainage Khals were subject to encroachment due to earth filling, deposition of city garbage and construction of building and roads. As a result, water logging has become a common phenomenon during monsoon in Dhaka city.

On the other hand, the present trends of residential land development in and around the city have posed environmental threat to the areas .The areas have been considered as reservoir for a long time where storm water of the city run off through internal Khals. The developing activities damage natural landscaping and changing the character of the areas. The urban upstream cannot discharge storm water adequately in the natural reservoir. Drainage congestion results in local floods with ankle to knee-deep water on the streets. This water logging problem is creating environmental and health hazard in the city (Nishat, et al., 2000). During field survey the respondent were asked about whether they are facing water logging in the area. Out of the 390 respondents 388 (99.49\%) respondents were replied that they are facing water logging problem. Respondent were also asked about hampering of daily work due to water logging. Around 96\% respondents were replied positively. Those who replied positively, they were asked which type of interruption they faced. There were four possible answers and others option for this question. 38.93\% respondents told that it is difficult to go work places. Another $30.93 \%$ and $14.13 \%$ respondent replied that it is not possible to move on foot and movement of vehicle disrupted, respectively (Table 4). It was observed during field visit that due to water logging problem heavy traffic congestion occurred on the streets in Dhaka city. Normal traffic movement hampered during rainfall over $25 \mathrm{~mm}$ and people loss their valuable time (Field Survey, 2009).

Table 4. Perception of respondents on interruption of daily work

\begin{tabular}{|c|c|c|}
\hline Categories & Frequency & Percentage \\
\hline \multicolumn{3}{|c|}{ Hampered daily work } \\
\hline Yes & 375 & 96.6 \\
\hline No & 13 & 3.4 \\
\hline Total & 388 & 100.0 \\
\hline \multicolumn{3}{|c|}{ Types of interruption of daily work } \\
\hline Not possible to move on foot & 116 & 30.93 \\
\hline Shops remain closed & 52 & 13.87 \\
\hline Difficult to go work places & 146 & 38.93 \\
\hline Movement of vehicles disrupted & 53 & 14.13 \\
\hline Others & 8 & 2.14 \\
\hline Total & 375 & 100.0 \\
\hline
\end{tabular}

Source: Field survey, 2009

Besides physical consequences of wetland change, in this study we also analyzed some environmental aspects/consequences of wetland change. The Data analysis of field survey shows that $69.5 \%, 0.9 \%, 16.7 \%$, $8.2 \%$, and $3.9 \%$ respondents are suffering from Diarrhoea, Malaria, Skin Disease, Dysentery and Typhoid, respectively (Figure 8). Therefore, Diarrhoea and Skin Disease are the main health environmental problems in the surveyed area Respondent were also asked about the types of unhygienic situations that created during the water logging in the area. Figure 9 shows that $38.4 \%$ respondents reported that mosquito increases during this time, while $25.5 \%$ reported spread of odor. Another $1.5 \%$ of the respondents mentioned that kitchen waste floats on water and 34.5\% reported waste of open drainage floats on water. Therefore, it may be said that in the water logging area physical environmental situation became worth due to wetland change and consequences. 


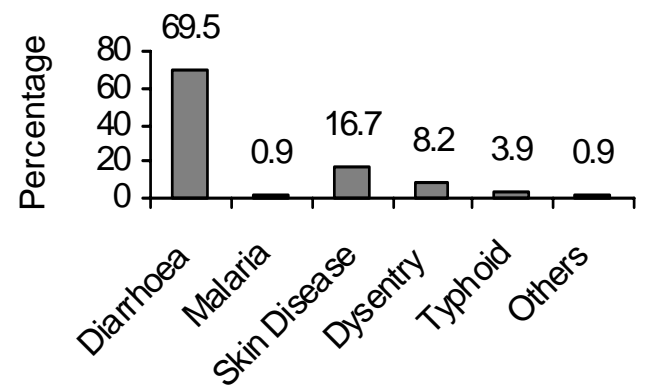

Fig. 8 Respondents' perception about suffering from diseases (Source: Field Survey, 2009)

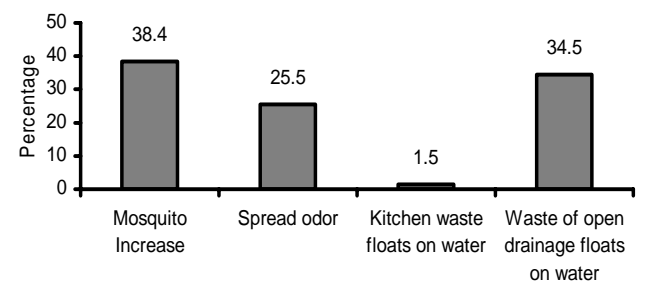

Fig. 9 Unhygienic situations created by water logging (Source: Field survey, 2009)

\section{Conclusion}

Dhaka city is expanding in an unplanned and uncontrolled manner. Rapid population growth creates extra pressure on the land of already over crowded Dhaka city. For this reason urbanization is stretching along/towards the wetlands. Though it is found that the main causes of wetland loss are unplanned urbanization and earths filling for construction of infrastructure, wetlands are randomly being filled up or encroached by mainly real estate housing companies and government organizations. It is revealed that in 1960, the area under wetlands was the highest, the landfill areas were the lowest and the built up areas were the second lowest land cover types in Dhaka city. But in 2008, the situation is changed and the built-up areas became the highest land cover types. The landfill areas increased about $382 \%$ in an average and built-up areas increased more than 385\% in 2008 compared to 1960. From 19602008, Dhaka has already lost $32.57 \%$ of water bodies and $51.58 \%$ of lowlands. On the other hand, field survey results revealed that drainage congestion and water logging are the main physical consequences of wetland loss. Severe water logging creates every year in the city during monsoon incurring huge loss in terms of adverse social, physical, economic and environmental losses. The remaining wetlands are crucial for Dhaka to keep the ecological balance, especially to reduce the water logging impacts.

\section{References}

BBS 2007. Bangladesh Population Census 2001, Community Series, Zila: Dhaka. Bangladesh Bureau of Statistics, Ministry of Planning, Government of the People's Republic of Bangladesh, Dhaka.

Dani AH. 1962. Dacca: A Record of Its Changing Fortunes. Ahmed Hasan Dani, Dhaka.

DOE BCAS and UNEP 2006. Dhaka City State of Environment 2005. United Nations Environment Programme.

Islam N. 2005. Dhaka Now Contemporary Urban Development. Bangladesh Geographical Society (BGS), Dhaka.

Islam T. 2002. Research Report on Evolution of Wetlands in Dhaka City. Department of Geography and Environment, Jahangirnagar University, Dhaka.

Jensen JR. 1996. Introductory Digital Image Processing: A Remote Sensing Perspective (2nd ed). Prentice Hall, New Jersey.

JICA, 1987. Study on Storm Water Drainage System Improvement Project in Dhaka City. Local Government Division, Dhaka.

JICA, 1991. Master Plan on Greater Dhaka Flood Protection Project. Flood Action Plan No. 8A, Supporting ReportI and II, Flood Plan Coordination Organization (presently WARPO), Dhaka.

Khan NI. 2001. Assessment of water logging conditions using integrated GIS and remote sensing techniques: A Study of Dhaka Mega City. Oriental Geographer 45(2): 41-54.

Khuda ZRMM. 2001. Environmental Degradation Challenges of the $21^{\text {st }}$ Century. Environmental Survey and Research Unit, Dhaka, Bangladesh.

Nakashima S and Khan MH 1994. A Basic Guide to Understanding the Environmental Impacts of Rural Roads on the Wetlands of Bangladesh. Care International, Bangladesh.

Nishat A, Reazuddin M, Amin R and Khan AR. 2000. The 1998 Flood: Impact on Environment of Dhaka City. Department of Environment and IUCN Bangladesh, Dhaka, Bangladesh.

RAJUK 1997. Dhaka Metropolitan Development Plan (19952015). Rajdhani Unnayan Kartripakha, Dhaka.

World Bank 2007. Dhaka Metropolitan Development Plan Strategic Environmental Assessment. Prepared by SENES Consultants Limited in Association with Techno Consult International Ltd. Dhaka, Bangladesh.

Yamane T. 1970. Statistics: An Introductory Analysis. Harper \& Row, New York.

Manuscript received on 13 July 2010 and revised on 5 December 2010. 